\title{
Effects of rhDNase on purulent airway secretions in chronic bronchitis
}

\author{
E. Puchelle*, J-M. Zahm*, S. de Bentzmann*,C. Grosskopf**, \\ S. Shak ${ }^{+}$, D. Mougel,++ J-M. Polu++
}

Effects of rhDNase on purulent airway secrections in chronic bronchitis. E. Puchelle, J-M. Zahm, S. de Bentzmann, C. Grosskopf, S. Shak, D. Mougel, J-M. Polu. (CERS Journals 1996.

ABSTRACT. Recombinant human deoxyribonuclease (rhDNase) has been demonstrated to reduce in vitro the viscosity and to improve the transport capacity of purulent respiratory mucus in cystic fibrosis. During episodes of exacerbation of chronic bronchitis, the patients generally expectorate purulent mucus. Purulence of mucus is associated with an increased deoxyriboneucleic acid (DNA) concentration.

We analyzed in vitro the potential effect of rhDNase on chronic bronchitis mucus transport by the ciliary activity (frog palate model) and by simulated cough (cough machine model), as well as the effect on mucus viscosity (controlled stress rheometer) and surface properties (contact angle). Purulent sputa collected from patients with chronic bronchitis $(n=15)$ during an episode of exacerbation were incubated for 30 min at $37^{\circ} \mathrm{C}$ with either rhDNase at two different concentrations (final concentration 2 or $4 \mu \mathrm{g} \cdot \mathrm{mL}^{-1}$ ) or placebo.

The median mucociliary transport rate was significantly improved by rhDNase from 0.68 with placebo to 0.79 and 0.83 with 2 and $4 \mu \mathrm{g} \cdot \mathrm{mL}^{-1}$ of rhDNase, respectively. A significant improvement in mucus cough transport was also induced by rhDNase from $25.5 \mathrm{~mm}$ with placebo to $27.0 \mathrm{~mm}$ with either 2 or $4 \mu \mathrm{g} \cdot \mathrm{mL}^{-1}$ rhDNase. These improvements in mucus transport capacity were associated with alterations in the physical properties of the mucus. The mucus median control viscosity (511.4 Pa.s) and median contact angle ( $0.85 \mathrm{rd})$ significantly decreased to $112.5 \mathrm{~Pa}$. .s and $0.74 \mathrm{rd}$, respectively, in the presence of $4 \mu \mathrm{g} \cdot \mathrm{mL}^{-1}$ of rhDNase.

These findings demonstrate that recombinant deoxyribonuclease may exert a beneficial effect on mucus clearance in vitro by altering the viscosity and surface properties of the purulent chronic bronchitic sputum samples. Eur Respir J., 1996, 9, 765-769.
*Unité INSERM 314, Université de Reims, France. **Roche, Neuilly, France. +Genentech, San Francisco, USA. ${ }^{++}$Service des Maladies Respiratoires, CHU Nancy Brabois, France.

Correspondence: E. Puchelle CHR Maison Blanche

45, rue Cognacq Jay

51092 Reims Cédex France

Keywords: Airway secretions chronic bronchitis cough transport mucociliary transport mucus rheology recombinant deoxyribonuclease

Received June 51995

Accepted after revision October 91995
Chronic obstructive lung diseases include several disease entities, such as chronic bronchitis (CB), chronic obstructive bronchiolitis (COB) and cystic fibrosis (CF). All these diseases include common features, such as mucous cell hyperplasia and metaplasia, hypersecretion of mucus, airway oedema and denudation of the lining epithelium, in which airway inflammation plays a key role [1]. In $\mathrm{CF}$, the frequent exacerbations of endobronchial infection by Pseudomonas aeruginosa are associated with a decreased mucociliary transport and with the accumulation of viscous and infected secretions [2, 3]. The persistence of infections due to the difficulty of eradicating $P$. aeruginosa provides a stimulus for the production of neutrophil chemotactic factors, that cause a marked increased influx of neutrophils to the lung [4]. The infiltration of the airway mucosa with neutrophils and the proteases released during inflammatory cell activation and phagocytosis lead to a massive accumulation of deoxyribonucleic acid (DNA) in the airway lumen and in mucus, which is derived from neutrophils and other exfoliated cells $[5,6]$.
Airway secretion purulence is generally associated with an increased DNA content and increased viscosity [7]. Nevertheless, some controversy exists in the literature on the specific role of DNA. In a group of CB sputum samples, we were unable to demonstrate a significant correlation between DNA, viscosity and elasticity of sputum [8]. A lack of correlation between DNA content and viscosity was further confirmed by PICOT et al. [9], suggesting that other biochemical constituents than DNA may participate in the increased viscosity of sputum in CB.

The highly purified recombinant human deoxyribonuclease (rhDNase) I was recently cloned and expressed [10]. In a recent study carried out in CF patients, we demonstrated that mucus viscosity closely correlates with DNA concentration and that the addition of rhDNase to these $\mathrm{CF}$ purulent sputum samples decreases the viscosity and improves the mucus transport capacity [11].

Airway infection associated with purulent sputum is also a common complication of chronic bronchitis. We have recently shown that children with recurrent bronchitis sustain a severe bronchial inflammation associated 
with an increased number of serum-derived proteins and leucocytes. Associated with a reduced mucus transport rate, these alterations may result in mucus obstruction of the airway [12].

To investigate the potential of rhDNase for the treatment of patients with chronic obstructive lung diseases other than $\mathrm{CF}$, we analysed the effect of rhDNase on the rheological and transport capacity of purulent sputum samples collected in patients with chronic bronchitis, who were admitted to hospital for an acute pulmonary exacerbation.

\section{Material and methods}

\section{Patients}

Fifteen patients ( 11 males and 4 females) with chronic bronchitis (characterized by cough and sputum production for more than 3 months a year over a duration of at least two successive years) were admitted to hospital for an acute pulmonary exacerbation defined according to the criteria described by ANTHONISEN et al. [13], including an increase in sputum production, purulence, dyspnoea, and a severe hypoxemia (arterial oxygen tension, $\left.P_{\mathrm{aO}_{2}}, 8 \mathrm{kPa}(<60 \mathrm{mmHg})\right)$. The forced expiratory volume in one second/forced vital capacity ratio (FEV1/FVC) expressed as percentage of predicted value was low (median $43 \%$ pred) and ranged $32-52 \%$ pred. The exclusion criteria were as follows: cystic fibrosis, radiological documented bronchiectasis or radiological parenchymal infection. The median age of the patients was 68 yrs (57-83 yrs). With one exception, they were all ex-smokers (30100 pack-years). They exhibited dyspnoea and hypoxaemia, $\mathrm{PaO}_{2}$ ranging $5.9-7.9 \mathrm{kPa}(44-59 \mathrm{mmHg})$. In five of the 15 patients, chest radiographs showed that chronic bronchitis was associated with emphysema.

\section{Airway secretion collection}

The samples of airway secretion were collected for 30 min by physiotherapy manoeuvres (percussion, vibration, breathing exercises) using dental cotton-wool swabs to limit the salivary contamination [14]. After expectoration, the secretions were gently aspirated in a plastic syringe which was then sealed and kept at $4^{\circ} \mathrm{C}$ during transportation by express mail ( 1 day) to the laboratory. The express mail conditions at $4^{\circ} \mathrm{C}$ temperature were satisfactorily controlled and did not induce any significant alterations in the rheological and physical properties of the native mucus (unpublished data). It is of interest to note that freezing and thawing of purulent CF sputum lead to a significant alteration in the physical surface properties of samples. The $\mathrm{CB}$ patients expectorated large volumes of sputum (50-100 mL·day ${ }^{-1}, \mathrm{n}=13$ and $>100 \mathrm{ml} \cdot$ day $\left.^{-1}, \mathrm{n}=2\right)$. All but two samples were infected by Haemophilus influenzae and/or Staphylococcus aureus.

\section{Study design}

For analysis, the sample of mucus was divided into three aliquots. Each aliquot was incubated for $30 \mathrm{~min}$ at $37^{\circ} \mathrm{C}$ either with placebo $\left(\mathrm{NaCl} 150 \mathrm{mM}+1 \mathrm{mM} \mathrm{CaCl}_{2}=\right.$ control) or with two different concentrations of rhDNase in placebo (final concentrations 2 or $4 \mu \mathrm{g} \cdot \mathrm{mL}^{-1}$ of mucus). These concentrations are representative of concentrations following inhalation of $2.5 \mathrm{mg}$ of rhDNase [15]. The volume of placebo or rhDNase diluted in placebo which was added to the mucus represented $4 \%$ of the volume of the mucus sample; it was gently mixed into the mucus for $5 \mathrm{~s}$ using a manual stirrer. After the incubation period, the viscoelastic and surface properties of each mucus aliquot were analysed. The transport of mucus by ciliary activity (frog palate model) and by cough (simulated cough machine) were also measured.

\section{Methods}

\section{Viscoelastic properties}

The viscoelastic properties of the mucus were analysed by using a controlled stress rheometer (TA Instruments) equipped with a cone-plate geometry [16]. The angle between the cone and the plate was 0.017 radian and the sample volume required was $20 \mu \mathrm{L}$. The measurements were carried out at $25^{\circ} \mathrm{C}$ using the creep test technique. A constant stress of $10 \mathrm{~Pa}$ was applied to the sample and the resultant strain was recorded versus time. When a steady flow was achieved, the applied stress was suppressed and the recovery angle $\gamma$ of the strain, representative of the mucus elasticity, was measured. The slope of the strain versus time curve was representative of the shear rate applied to the mucus sample. The ratio shearstress/shear rate and the ratio shear stress/shear strain allowed the mucus viscosity and the mucus elastic modulus, respectively, to be calculated.

\section{Surface properties}

The surface properties of the mucus were analysed by measuring the contact angle of a $20 \mu \mathrm{L}$ drop of mucus, which was deposited on a glass slide in a small chamber with $100 \%$ relative humidity. An image analysis technique was used to measure the angle between the tangent to the mucus/air interface and the horizontal at the contact point of the drop of mucus with the glass slide [17].

\section{Transport of mucus by cough}

Experiments were performed using the cough machine developed by King et al. [18]. A tank of 6L in volume was used as a reservoir for pressurized air and was connected through a solenoid valve to a plastic tube simulating the trachea. The floor of this tube was made by the glass slide, on which the drop of mucus used for contact angle measurement was deposited. A cough was simulated by opening the solenoid valve, releasing the pressurized air through the model trachea in which the airflow was $6 \mathrm{~L} \cdot \mathrm{s}^{-1}$. The distance travelled by the mucus under the effect of the airflow was measured and represented the mucus cough transport. According to the volume of mucus collected, one or two measurements were made for each aliquot. 
Transport of mucus by ciliary activity

In vitro measurements of the transport of mucus by ciliary activity were made using the frog palate technique [19]. Isolated palates from frogs (Rana esculenta) were placed in a plexiglass chamber at a controlled temperature $\left(25^{\circ} \mathrm{C}\right)$ and in $100 \%$ relative humidity. After $24 \mathrm{~h}$, the endogenous mucus secretion of the isolated palate was exhausted but the cilia remained active. This depleted palate was used to measure the mucociliary transport both of the control frog mucus and the $\mathrm{CB}$ respiratory mucus. A drop of mucus $(1 \mu \mathrm{L})$ taken from the palate of a recently killed frog was placed on the depleted palate and its transport velocity was measured by following the displacement, through a stereomicroscope, of a calibrated aluminium disc (600 $\mu \mathrm{m}$ in diameter) placed on the mucus drop. Thereafter, the transport velocity of the $\mathrm{CB}$ respiratory mucus aliquots was measured in the same manner, and the results were expressed as relative transport rate, corresponding to the ratio of $\mathrm{CB}$ respiratory mucus transport rate to the control frog mucus transport rate, both being measured on the same depleted frog palate. Three measurements were made for each mucus aliquot.

\section{Measurement of total DNA content}

Mucus DNA content was determined by the modified diaminobenzoic acid (DABA) assay [20] developed by KissANe and RoBINs [21]. Briefly, mucus was diluted 10 fold with diluent ( $25 \mathrm{mM}$ hydroxyethylpiperazine ethanesulphonic acid (HEPES), $1 \mathrm{mg} \cdot \mathrm{mL}^{-1}$ bovine serum albu$\min (\mathrm{BSA}), 4 \mathrm{mM} \mathrm{CaCl}, 0.05 \%$ polysorbate 20 , and $0.01 \%$ thimerasol, $\mathrm{pH} 7.5$ ) and incubated at $60^{\circ} \mathrm{C}$ for $1 \mathrm{~h}$. Fifty microlitres of the diluted mucus was incubated in microtitre plate wells with $50 \mu \mathrm{L}$ of $20 \%$ 3,5-diaminobenzoic acid hydrochloride solution at $60^{\circ} \mathrm{C}$ for $1 \mathrm{~h}$. Fifty $\mu \mathrm{L}$ of $5 \mathrm{~N} \mathrm{HCl}$ was then added to stop the reaction. Fluorescence was measured in a microtitre plate fluorometer (with $390 \mathrm{~nm}$ excitation and $530 \mathrm{~nm}$ emission filters). Salmon testes DNA (Sigma) was used to establish the standard curve. This assay, which measures total DNA

a)

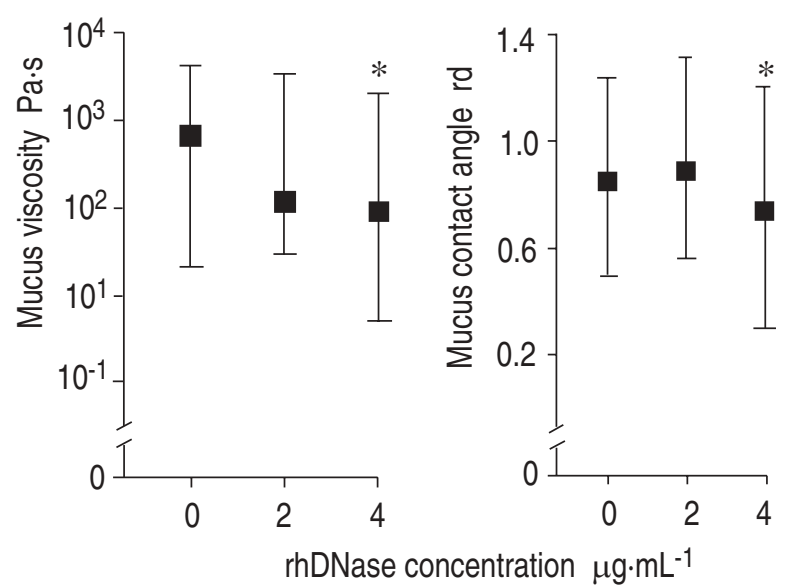

Fig. 1. - Effect of recombinant dioxyribonuclease (rhDNase) on: a) the mucus viscosity; and b) the mucus angle of contact after incubation with 2 and $4 \mu \mathrm{g} \cdot \mathrm{mL}^{-1}$ of rhDNase. The differences were tested by the nonparametric Wilcoxon test. The data are expressed as median values and interquartile ranges. *: $\mathrm{p}<0.05$ vs control.

concentration independent of its length, was performed on all 15 samples.

\section{Statistical analysis}

All the data are expressed as a median value and interquartile range. The Spearman correlation test was used to relate the DNA content to the rheological and surface properties of mucus. The nonparametric KruskalWallis test was used to analyse the dose-dependent effect of rhDNase on the rheological and functional properties of mucus. The nonparametric Wilcoxon test was used to compare the control mucus with the DNase-treated mucus. A p-value of less than 0.05 was considered to be significant.

\section{Results}

The DNA content in the 15 sputum samples collected in the $\mathrm{CB}$ patients ranged from $0.4-6.8 \mathrm{mg} \cdot \mathrm{mL}^{-1}$ (median $\left.1.8 \mathrm{mg} \cdot \mathrm{mL}^{-1}\right)$. The sputum DNA content of the CB patients was thus much lower $(\mathrm{p}<0.01)$ compared to the DNA content of CF sputum samples (median $8.5 \mathrm{mg} \cdot \mathrm{mL}^{-1}$, range $2.4-19.4 \mathrm{mg} \cdot \mathrm{mL}^{-1}$ ) that we had analysed previously [11]. In our population of CB patients, no correlation could be demonstrated between the DNA content and the mucus viscosity $(\mathrm{r}=0.10 ; \mathrm{p}>0.78)$. Very close low values of DNA (e.g. 0.6 and $0.4 \mathrm{mg} \cdot \mathrm{mL}^{-1}$ ) could be observed for a wide range of values of mucus viscosity (20 and $3.7 \times 10^{3} \mathrm{~Pa} . \mathrm{s}$, respectively).

Compared to control (median viscosity 511.4 Pa.s), a progressive decrease in the mucus viscosity was observed at a rhDNase concentration of 2 and $4 \mu \mathrm{g} \cdot \mathrm{mL}^{-1}$ (median 118.4 and 112.5 Pa.s, respectively) (fig. 1a). At a concentration of $4 \mu \mathrm{g} \cdot \mathrm{mL}^{-1}$, the decrease of viscosity was significant $(p<0.03)$ as was the decrease $(p<0.05)$ in mucus contact angle (fig. 1b). Although the elastic modulus decreased in association with the increase of rhDNase

a)

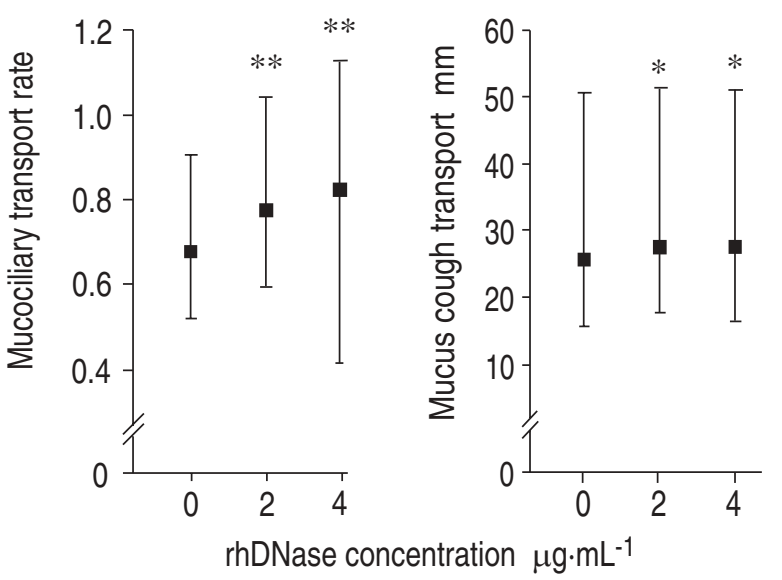

Fig. 2. - Effect of recombinant deoxyribonuclease (rhDNase) on: a) the in vitro mucociliary transport rate; and b) the mucus cough transport after incubation with 2 and $4 \mu \mathrm{g} \cdot \mathrm{mL}^{-1}$ of rhDNase. **: $\mathrm{p}<0.01$; $*: \mathrm{p}<0.05$ vs control. The differences were tested by the nonparametric Wilcoxon test. The data are expresses as median values and interquartile ranges. 
concentration (control median elastic modulus $19.6 \mathrm{~Pa}$; $12.2 \mathrm{~Pa}$ at a rhDNase concentration of $2 \mu \mathrm{g} \cdot \mathrm{mL}^{-1}$ and $11.3 \mathrm{~Pa}$ at a rhDNase concentration of $\left.4 \mu \mathrm{g} \cdot \mathrm{mL}^{-1}\right)$, the differences were not significant.

An increase in mucociliary transport rate was also obser-ved (fig. 2a). Compared to control values (median 0.68 ) the mucociliary transport rate was significantly $(\mathrm{p}<0.01)$ higher at rhDNA concentration of 2 and 4 $\mu \mathrm{g} \cdot \mathrm{mL}^{-1}$ (median 0.79 and 0.83 , respectively). The mucus cough transport also significantly $(\mathrm{p}<0.05)$ improved after rhDNase (median control $25.5 \mathrm{~mm} ; 27.0 \mathrm{~mm}$ at rhDNAase concentration of $2 \mu \mathrm{g} \cdot \mathrm{mL}^{-1}$ and at $\left.4 \mu \mathrm{g} \cdot \mathrm{mL}^{-1}\right)$.

\section{Discussion}

This in vitro study demonstrates that, in chronic bronchitic patients, with purulent expectorations collected during an exacerbation of their disease, the addition of rhDNase to sputum at a final concentration of 2 and 4 $\mu \mathrm{g} \cdot \mathrm{mL}^{-1}$ significantly improves the mucociliary and cough transport in association with a significant decrease only at the concentration of $4 \mu \mathrm{g} \cdot \mathrm{mL}^{-1}$ in the rheological (viscosity) and surface (angle of contact) properties of airway secretions.

Abundant and purulent airway secretion is not only a hallmark of CF lung disease and is also common in other obstructive lung diseases. The term "chronic obstructive pulmonary disease" (COPD) refers to a spectrum of chronic bronchitic diseases characterized by cough, sputum production, dyspnoea, airflow limitation and gas exchange, very often associated with inflammation. Studies of lung biopsies and bronchoalveolar lavages have shown that the airway mucosal and luminal inflammation correlated with hypersecretion and sputum purulence [22].

The fifteen in-patients included in our study all had a history of chronic bronchitis and were admitted to the hospital for an acute pulmonary exacerbation. All the CB patients expectorated purulent secretions. Six of them expectorated more than $80 \mathrm{~mL}$ of sputum per day. Huge variations of the viscosity and surface properties were observed from one patient to another (viscosity range 19.4-3750 Pa.s and angle of contact range 0.48-1.23 rd) but we could not demonstrate any significant correlation between the DNA content and the viscosity $[8,9]$. This is in apparent disagreement with the results reported previously in $\mathrm{CF}$, where a significant and close $(\mathrm{r}=0.82$; $\mathrm{p}<0.01$ ) relationship was demonstrated between the DNA content and the viscosity of sputum samples [11]. This may result from the fact that, compared to the previous group of CF sputum samples, the range of sputum DNA content is much smaller in this group of $\mathrm{CB}$ (range of DNA $0.4-6.8 \mathrm{mg} \cdot \mathrm{mL}^{-1}$ in the CB patients and $2.4-19.5$ $\mathrm{mg} \cdot \mathrm{mL}^{-1}$ in the $\mathrm{CF}$ patients). A high median DNA content $\left(2.9 \mu \mathrm{g} \cdot \mathrm{mL}^{-1}\right)$ was associated with the eight sputum samples characterized by a low mucociliary transport rate $(\leq 0.7)$. In contrast, the median DNA content was lower $\left(1.3 \mu \mathrm{g} \cdot \mathrm{mL}^{-1}\right)$ in the seven sputum samples characterized by a high mucociliary transport range $(>0.7)$. Nevertheless, no significant correlation could be identified between the DNA content and the transport rate. Moreover, the range of DNA content in CB sputum samples contrasts with the huge range of viscosity values and confirms that in $\mathrm{CB}$, in addition to DNA concentration, other factors, such as mucins, proteins and lipids, contribute to the rheological and physical properties of airway secretions [3]. Nevertheless, incubation of sputum from CB patients with rhDNase leads to an improvement in mucociliary clearance associated with alterations of the rheological and physical properties of sputum.

As shown in table 1, the rheological and physical properties of CF sputum samples reported previously [11] appear to be more sensitive to rhDNase as compared to those of this group of $\mathrm{CB}$ sputum samples. At a similar concentration of rhDNase $\left(2 \mu \mathrm{g} \cdot \mathrm{mL}^{-1}\right)$, the percentage decrease in viscosity is twofold higher in CF compared to CB. Nevertheless, this latter decrease in viscosity of $\mathrm{CB}$ sputum is sufficient to normalize the mucociliary transport rate of these secretions.

It is of interest to note that of the eight $\mathrm{CB}$ patients who initially demonstrated a low mucociliary transport rate (ranging 0.52-0.63), six had a normal mucociliary transport rate after incubation with rhDNase concentration of $4 \mu \mathrm{g} \cdot \mathrm{mL}^{-1}$. Importantly, in the seven patients with a relatively high transport rate $(>0.70)$, none demonstrated a decreased mucociliary transport capacity after rhDNase incubation. In fact, five of the seven sputum samples with an initial relatively high transport rate further increased their transport rate after incubation with rhDNase, either at 2 or $4 \mu \mathrm{g} \cdot \mathrm{mL}^{-1}$. Concerning the surface properties of airway secretions, we observed, as we had previously reported in a group of CF patients [11], that rhDNase at a concentration of $4 \mu \mathrm{g} \cdot \mathrm{mL}^{-1}$ is able to decrease the mucus contact angle. This change reflects a decrease in mucus surface tension, generally associated with a decrease in the adhesive properties of mucus and a parallel improvement in the cough and ciliary transport capacity. As suggested for $\mathrm{CF}$ secretions, the decrease in the adhesive properties of $\mathrm{CB}$ secretions observed with rhDNase could also represent an indirect effect of rhDNase, for example the recovery of surface-active molecules, such as phospholipids, which could be dissociated from DNA molecules present in the mucus. Such changes are likely to be responsible for the significant improvement observed in the cough and ciliary clearability of the CB sputum samples incubated with rhDNase.

Taken together, these results suggest that the administration of aerosolized recombinant deoxyribonuclease may be beneficial to chronic obstructive pulmonary disease patients with airway inflammation, hypersecretion and purulent sputum. This benefit is suggested by the reduction in sputum viscosity, the increase in mucus transportability and the increase in cough clearance of purulent sputum collected in our group of 15 chronic bronchitic

Table 1. - Comparison of the median percentage change in the rheological and transport properties of secretions from chronic bronchitis (this study) or cystic fibrosis patients (from [11]) after incubation with rhDNase at a final concentration of $2 \mu \mathrm{g} \cdot \mathrm{mL}^{-1}$

\begin{tabular}{lcccc}
\hline Patients & $\begin{array}{c}\text { Viscosity } \\
\%\end{array}$ & $\begin{array}{c}\text { Contact } \\
\text { angle } \%\end{array}$ & $\begin{array}{c}\text { Cough } \\
\text { transport\% }\end{array}$ & $\begin{array}{c}\text { Mucociliary } \\
\text { transport \% }\end{array}$ \\
\hline $\mathrm{CB}(\mathrm{n}=15)$ & -4 & -1 & +6 & +9 \\
$\mathrm{CF}(\mathrm{n}=15)$ & -87 & -17 & +29 & +36
\end{tabular}

rhDNase: recombinant deoxyribonuclease; $\mathrm{CB}$ : chronic bronchitis; CF: cystic fibrosis. 
patients. It is well-known that the development of chronic bronchitis is mainly related to an inflammatory process. Not only adults but also children with recurrent bronchitis, outside of an episode of superinfection, maintain severe bronchial inflammation [12]. The mucosal inflammation characterized by an intraepithelial infiltration and oedema, and a shedding of the surface epithelial cells associated with a decreased mucociliary transport suggest that, apart from inflammatory cells, exfoliated epithelial cells may also contribute to an increased content of deoxyribonucleic acid with a resulting hyperviscosity of sputum. Whether recombinant deoxyribonuclease may lead to clinical benefit in such patients remains to be determined.

\section{References}

1. Ferguson GT, Cherniak RM. Management of chronic obstructive pulmonary disease. N Engl J Med 1993; 328: 1017-1022.

2. Boat TF. Cystic fibrosis. In: Murray JF, Nadel JA. eds. Textbook of Respiratory Medicine. Philadelphia, Pa, W.B. Saunders Co., pp. 1988, 1126-1152.

3. Puchelle E, Jacquot J, Beck G, Zahm JM, Galabert C. Rheological and transport properties of airway secretions in cystic fibrosis; relationships with the degree of infection and severity of the disease. Eur J Clin Invest 1985; 15: 389-394.

4. Lethem M, Stuart L, Marriott C. The role of mucus glycoproteins in the rheologic properties of cystic fibrosis sputum. Am Rev Respir Dis 1990; 142: 1053-1058.

5. Massion $\mathrm{P}$, Inoue $\mathrm{H}$, Richman-Elsenstat $\mathrm{J}$, et al Novel Pseudomonas product stimulates interleukin-8 production in airway epithelial cells in vitro. $J$ Clin Invest 1994; 93: 26-32.

6. Potter J, Matthews LW, Lemm J, Spector S. The composition of pulmonary secretions from patients with and without cystic fibrosis. Am J Dis Child 1960; 100: 493-495.

7. Chernick WS, Barbero GJ. Composition of tracheobronchial secretions in cystic fibrosis of the pancreas and bronchectasis. Pediatrics 1959; 24: 739-745.

8. Puchelle E, Zahm JM, Havez R. Données biochemiques et rhéologiques dans l'expectoration: relation des protéines et mucines bronchiques avec les propriétés rhéologiques. Bull Physiopath Resp 1973; 9: 237-257.

9. Picot R, Das I, Reid L. Pus, deoxyribonucleic acid and sputum viscosity. Thorax 1978; 33: 235-242.
10. Shak S, Capon DJ, Hellmiss R, Marsters SA, Baker CL. Recombinant human DNase reduces the viscosity of cystic fibrosis sputum. Proc Natl Acad Sci 1990; 87: 9188-9192.

11. Zahm JM, Girod de Bentzmann S, Deneuville E, et al. Dose-dependent in vitro effect of recombinant human DNase on the rheological and transport properties of cystic fibrosis respiratory mucus. Eur Respir $J$ 1995; 8: 381-386.

12. Gaillard D, Jouet JB, Egreteau L, et al. Airway epithelial damage and inflammation in children with recurrent bronchitis. Am J Respir Crit Care Med 1994; 150: 810-817.

13. Anthonisen NR, Manfreda J, Warren CPW, Hershfield ES, Harding GKM, Nelson NA. Antibiotic therapy in exacerbations of chronic obstructive pulmonary disease. Ann Intern Med 1987; 106: 196-204.

14. Puchelle E, Tournier JM, Zahm JM, Sadoul P. Rheology of sputum collected by a simple technique limiting salivary contamination. J Lab Clin Med 1984; 103: 347-353.

15. Sinicropi DV, Williams M, Prince WS, et al. and the DNase Clinical Investigators. Sputum pharmacodynamics and pharmacokinetics of recombinant human DNase I in cystic fibrosis. Am J Respir Crit Care Med 1994; 149: A671.

16. Puchelle E, Zahm JM, Duvivier C, Didelon J, Jacquot J, Quemada D. Elasto-thixotropic properties of bronchial mucus and polymer analogs. Biorheology 1985; 2: 415423.

17. Vaquez-Girod S, Zahm JM, Dionisius JP, Pierrot D, Puchelle E. Automatic measurement of the wetting properties of fluids. Innov Tech Biol Med 1988; 9: 402-412.

18. King M, Brock G, Lundell C. Clearance of mucus by simulated cough. J Appl Physiol 1985; 58: 1776-1782.

19. Puchelle E, Tournier JM, Petit A, et al. The frog palate for studying mucus transport velocity and mucociliary frequency. Eur J Respir Dis 1983; 64: 293-303.

20. Sinicropi D, Prince W, Williams M, et al. Measurement of DNA concentration and length in cystic fibrosis sputum. Ped Pulm 1994; Suppl. 10: 238.

21. Kissane JM, Robins E. The fluorometric measurement of deoxyribonucleic acid in animal tissues with special reference to the central nervous system. J Biol Chem 1958; 233: 184.

22. Konstan M, Hilliard KA, Norwel TM, Berger M. Bronchoalveolar lavage findings in cystic fibrosis patients with stable, clinically mild lung disease suggest ongoing infection and inflammation. Am J Respir Crit Care Med 1994; 150: 448-454. 